\title{
Servive Quality on Education Institution: Satisfaction Index and IPA (Case Study on Accounting Department of State Polytechnic of Malang)
}

\author{
Sumiadji ${ }^{*}$, Futuh Handoyo ${ }^{2}$, Fita Setiati ${ }^{3}$ \\ ${ }^{123}$ Accounting Department, State Polytechnic of Malang, East Java, Indonesia
}

\section{A R T I C L E I N F O}

\section{Article history:}

Received 19 August 2019 Received in revised form 16 September 2019 Accepted 15 October 2019

Available online 29

November 2019

\section{Keywords:}

service quality, student satisfaction index, importance-performance analysis

\section{A B S T R A C T}

The purpose of this study was to determine the level of student satisfaction towards the quality of service provided by the Accounting Department, State Polytechnic of Malang (Polinema), by comparing the actual service delivered by the institution to the one expected by the students. Respondents as samples were determined proportionally for each study program and class of as many as 100 students. The questionnaire was randomly given to respondents to obtain a response to service quality consisting of 5 (five) dimensions, namely tangible, reliability, responsiveness, assurance and empathy. Data analysis was descriptive analysis prosiding from descriping the data in term of the mean and frequency, and than measuring student satisfaction index and ending up with determining the service quality using importanceperformance analysis (IPA). The results showed that most respondents were DIV Management Accounting study program students, of whom the majority were female. The frequency of the students response for the quality of the received service fell into the catagory of very satisfying, which means that, in general, the quality of service received by students was very satisfying. There were found two dimensions in quadrant $A$ where two forms of service quality must be improved immediately, four dimensions in quadrant B where six forms of service quality must be maintained, and all dimensions in quadrant $D$ where eight forms of service quality in the short term may be ignored.

\footnotetext{
* Corresponding author.

E-mail addresses: sumiadji45@gmail.com (Sumiadji)
} 


\section{Introduction}

The Accounting Department is one of the departments of commerce faculties in the State Polytechnic of Malang (Polinema) which was established in 1986. In the effort to improve services to students as customers, the Accounting Department continously evaluates and improves its management. Regarding students as customers, department management must know the extent of student satisfaction with the service quality provided both academic and non-academic services. In addition, it is also necessary to identify service performance indicators, especially service indicators that need to be corrected immediately. This research exploratively provided important information on the level or index of satisfaction of Accounting Department students and described indicators of service quality expected by the students and the actual service quality delivered to them, which would definitely be useful for future corrective action.

Oldfield and Baron (2000) state that the world of higher education can be seen as a service industry; therefore, student satisfaction as a customer is very important. Student satisfaction is a great concern of every university. Arambewela and Hall (2009) state that satisfied students can be a source of competitive advantage that will produce communication in the form of positive word of mouth, student retention and loyalty. In the world of higher education where students are seen as consumers, the concept of student satisfaction is the main key to service success. Now, tertiary education providers are beginning to realize that the institutions they run resemble businesses that operate in the service industry (Asih, 2011). One uniqueness in providing services in higher education is the relationship with customers based on membership relationships, where customers have become members of certain educational institutions (Lupiyoadi and Hamdani, 2008).

There are two important things necessary for universities to survive and gain acceptance by public, namely the guarantee of service quality and external performance. According to Kotler (2002: 83) quality of service is any form of corporate activity carried out to meet consumer expectations. Service quality is a measure of how well the level of service provided is in accordance with customer expectations. Parasuraman et al., (1995) states that service quality is the customer's perception of service excellence. Only customers can judge whether a company's service quality is good or not. Service quality can be measured through a comparison between the services offered and the perception of customer acceptance whether it is in line with customer expectations or not. If the services delivered are in accordance with customer expectations, the quality of the service is said to be good and vice versa.

Indicators for measuring service quality, such as SERVQUAL and its modification, have been used by several organizations in the service industry (Bindu et al., 2009). Service quality dimensions according to Parasuraman, et al., (1995) are reduced from ten dimensions to five important dimensions that determine the level of service quality, namely: (a) tangible dimensions (direct evidence) which comprise physical appearance, equipment, and communication facilities, for example beauty office interiors, cleanliness and completeness of the office, neatness of the appearance of employees, harmony of office layout, ease and security of parking spaces, as well as completeness of telecommunications facilities, (b) reliability dimension, which refers to the ability to perform services as promised accurately and reliably for example, the fulfillment of customer desires and the timeliness provided, (c) responsiveness dimension), which represents the willingness to help customers and provide immediate service, for example, the certainty of the length of service and the readiness of employees in serving customers, (d) assurance dimension (guarantee), which refers to knowledge, manners, and the ability of employees to sustain trust and confidence, for example politeness, friendliness, and knowledge of the staff in the institution, and (e) empathy dimension (caring), which points to the individual care and attention given by the company to customers, for example an individual approach to customers and the creation of a good relationship with customers.

Another important thing is the output performance of the service provision. The purpose of providing services to customers is to provide customer satisfaction. Level of satisfaction refers to a feeling of pleasure or disappointment arising after comparing between the received and and expected service (Kotler and Keller, 2006). Zeithaml et al. (1996) defines satisfaction as a customer response regarding the needs to fulfillment. Customer satisfaction shows customer experience in influencing the service quality received and the value of service (Andreassen and Lindestad, 1997). The essence of customer satisfaction is costumers' behavioral responses in the form of an after-purchase evaluation of a product or service recieved compared to their expectations.

The level of service quality received by customers can be stated in terms of customer satisfaction index. The satisfaction index is a number that describes the level of satisfaction received by service customer (Algifari, 2019: 61). Student satisfaction index is obtained from a score scale of the measurement for the servive quality received by the students. The index is determined based on the range 
of the score scale for example a score of 1 to 4 or a score of 1 to 5 . Based on the satisfaction index, the category of satisfaction received will be identified from very unsatisfying to very satisfying (Algifari, 2019: 54). Through the score, the calculation can be made fo the percentage of service quality received for service quality againts the expected one (Algifari, 2019: 68).

Research related to service quality or level of student satisfaction was carried out by Ambartiasari et al. (2017) and Bhakti and Rahmawati (2017). Ambartiasari et al. (2017) investigated the effect of service quality, trust and campus facilities on satisfaction and its impact on the loyalty of Politeknik Indonesia Venezuela students. The results showed that service quality had a positive effect on student satisfaction. Bhakti and Rahmawati (2017) conducted a study aimed at finding out the level of satisfaction of mathematics education students towards the service quality of study programs. Aspects that were reviewed to determine the satisfaction of mathematics education study program services were based on five dimensions, namely tangibles, reliability, responsiveness, assurance and empathy. The results showed, in general, the level of satisfaction of mathematics education students towards the service of study programs in terms of five dimensions was quite satisfying.

That the response to the services provided is low does not necessarily mean that the dimensions of the service must be corrected immediately, but it may simply be due to the fact that the customer does not consider them important. Importance-Performance Analysis (IPA) specifically describes the expected service quality matrix of service importance againts the given performance, which are categorized in certain quadrants. Importance-Performance Analysis (IPA) was introduced by Martilla and James (1977) which is a multi-attribute model and can be used to analyze organizational performance. The IPA model is used to measure the satisfaction performance that is considered important by the customer and the satisfaction performance received by the customer which is grouped into four quadrants, namely quadrants A, B, C and D. Each quadrant relies on the performance of the product or service being valued, between expectations and reality. Figure 1 shows the cartesian degree diagram of the ImportancePerformance Analysis (IPA) model developed by Martilla and James (1977).

\begin{tabular}{|c|c|}
\hline $\begin{array}{c}\text { Quadrant A: Top Priority } \\
\text { Quality of service must be } \\
\text { improved }\end{array}$ & $\begin{array}{c}\text { Quadrant B: Maintain } \\
\text { Performance } \\
\text { Quality of service must be } \\
\text { maintained }\end{array}$ \\
\hline $\begin{array}{c}\text { Quadrant C: Low Priority } \\
\text { The quality of service can be } \\
\text { ignored, but it is better if it is } \\
\text { improved }\end{array}$ & $\begin{array}{c}\text { Quadrant D: Excessive } \\
\text { Quality of service can be } \\
\text { ignored }\end{array}$ \\
\hline
\end{tabular}

Figure 1. Cartesian Degrees Diagram - Model Importance-

\section{Performance Analysis}

Quadrant A illustrates that customers consider a service to be very important, so that the they have high expectations for the service, but the institution does not provide good service. Quadrant A indicates that the institution must concentrate on improving its performance on this indicator (concentrate here). Quadrant B describes services that are considered very important for customers, and the institution has provided good service to customers for this indicator. The quality of services provided in the indicators in quadrant B needs to be maintained (keep up the good work). Quadrant C in describes services that are considered less important by customers and the institution also provides low services to customers. Service in quadrant C is a low priority. Quadrant D describes the area of the indicator that is considered less important for customers, but the institution provides a good service. Quadrant D is an area called possible overkill.

The research that has proven the usefulness of the IPA was conducted by Kardoyo and Nurkhin (2016) which examines the satisfaction of students, graduates and graduates user using the SERVQUAL, an instrument developed by Parasuraman et al. (1985). One analysis using importance-performance analysis (IPA), shows that there are two dimensions of service that must be a top priority for immediate improvement, namely the access dimension and the reliability dimension. 


\section{Methods}

The population of this study was all active student of Accounting Department, who had received at least for one academic year (two semesters) in the even semester 2018/2019 as many as 1593 . The number of samples was determined using the Slovin formula (Sanusi, 2014: 101) with the percentage of inaccuracy $10 \%$ obtained 100 respondents, then counted proportionally for each study program and class

The instrument used in the study was a questionnaire. The questionnaire was given randomly, not pointing to spesified respondent, so anyone could give an answer. Research data through questionnaires to obtain responses to service quality which consists of 5 (five) dimensions of service, namely tangible, reliability, responsiveness, assurance and empathy (Parasuraman et al., 1985) where each dimension consists of some statements (indicators). The instrument shows the indicators stated in the form of a statement, used in the five dimensions depending on the form of service provided by the Accounting Department of State Polytecnich of Malang as many as 16 (sixteen) statements, consisting of:

a) Instruments in tangible dimensions showing physical appearance, availability and sophistication of equipment, are as follows:

1) Availability of classrooms and laboratory for the teaching learning process (P1)

2) Availability of equipment in the classroom / laboratory room (Computer / LCD / AC) for the learning process (P2)

3) Sophisticated technology / equipment used in the learning process (P3)

b) Instruments on the reliability dimension showing the ability, reliability and timeliness to carry out the services provided, are as follows:

1) The ability of lecturers in delivering learning material (P4)

2) Punctuality of lecturers in carrying out learning activities (P5)

3) Teaching skill for practical subjects (P6)

c) Instruments on the responsiveness dimension showing responsiveness, willingness and readiness to help customers and provide immediate service, are as follows:

1) The speed of the institution response to events and feedback (P7)

2) Seriousness of administrative staff in providing services (P8)

3) Willingness of lecturers to provide services outside teaching hours (P9)

d) Instruments on the assurance dimension showing guarantees of knowledge, courtesy, and the ability of employees to generate customer trust and confidence, are as follows:

a. Expertise and skills possessed by administrative staff in providing services (P10)

b. The polite attitude of administrative staff in providing services (P11)

c. Responsibilities of administrative staff in providing services (P12)

d. Ability to provide security and assertiveness of administrative staff in delivering services (P13)

e) Instruments on empathy dimensions that show caring and attention and individual approach to customers are as follows:

1) The willingness of the institution to listen to student complaints (P14)

2) Communication between the institution and students (P15)

3) The availability of administrative staff and other personnels in the institution during service hours (P16)

The expected service quality was measured in terms of the students perceived level of the importance of the service. It was ranked and classified into four scales and catagories, namely, 1 as Very Unimportant, 2 as Not Important, 3 as Important and 4 as Very Important. Similarly, the actual service quality was also ranked and classified into four with score 1 as Very Unsatisfying, 2 as Not Satisfying, 3 as Satisfying, and 4 as Very Satisfying.

Data analysis was descriptive analysis prosiding from descriping the data in term of the mean and frequency, and than measuring student satisfaction index and ending up with determining the service quality using importance-performance analysis (IPA). The processing and analysis phase invoved checking the completeness and clarity of respondents' answers, tabulating data, testing validity and reliability, performing descriptive analysis, calculating student satisfaction index (SSI) of all indicators on all dimensions of service quality received (with 4 ranges shown in the table 1) and identifying the position of each indicator of all dimensions in the IPA quadrant. 
Table 1. Student Satisfaction Index (SSI) Categorization

\begin{tabular}{|l|l|l|l|l|}
\hline No. & Interval Value SSI & Conversion Interval Value SSI & Quality Service & Performance \\
\hline 1 & $1,00-1,75$ & $25,00-43,75$ & D & $\begin{array}{l}\text { Very } \\
\text { Unsatisfying }\end{array}$ \\
\hline 2 & $1,76-2,50$ & $43,76-62,50$ & C & Not Satisfying \\
\hline 3 & $2,51-3,25$ & $62,51-81,25$ & B & Satisfying \\
\hline 4 & $3,26-4,00$ & $81,26-100,00$ & A & $\begin{array}{l}\text { Very } \\
\text { satisfying }\end{array}$ \\
\hline
\end{tabular}

Source: Algifari (2019: 66)

\section{Result and Discussion}

The questionnaire response rate for student respondents is very good, as $100 \%$ of the questionnaire was returned and can be processed. This can be understood because of the ease of obtaining data from respondents, namely students. The respondent's identity was composed of $32(32, \%)$ from DIII Accounting Study Program respondents with 12 (38\%) being male respondents and 20 (63\%) female respondents, 55 (55\%) from DIV Management Accounting Study Program with 19 (35\%) of male respondents and $36(65 \%)$ of female respondents, and 13 (13\%) from DIV Finance Study Program with the number of male respondents of 3 (34\%) and female respondents of as msny as 10 (66) \%). The frequency of the answers to the service quality expected by students are: very unimportant (score 1) totalling to $0(0 \%)$, not importance (score 2 ) totalling to $1(0 \%)$, importance (score 3 ) totalling to 230 $(14 \%)$, and very importance (score 4) totalling to 1369 (86\%). The frequency of the answers to the service quality received by students are: very unsatisfying (score 1) totalling to $11(1 \%)$, not satisfying (score 2) totalling to $93(6 \%)$, satisfying (score 3 ) totalling to $361(23 \%)$, and very satisfying (score 4 ) totalling to $1135(71 \%)$.

The results of the validity test of the two questionnaire expectations (importance) and reality (actual performance), showed that all indicators on all dimensions are valid as indicated by the significance level of correlation coefficients of $1 \%$ and $5 \%$. The results of the reliability test were carried out after the validity test by calculating the value of Cronbach's Alpha, which showed that the response to both, the questionnaire for expectations (importance) and the questionnaire for reality (actual performance) were reliable as shown by Cronbach's Alpha values respectively of 0.745 and 0.694, greater than 0.6 .

In general, the average service satisfaction index provided by the Accounting Department was very satisfying with an average score of 3.64 with an average level of satisfaction (conversion) of 90.94. Each indicator shows a very satisfying service quality except indicator (P1) on tangible dimensions of 2.70 and indicator (P6) on the reliability dimension of 2.57 which fall into the catagory of satisfying service quality. The ability of the Accounting Department in realizing services expected by students reaches $93.5 \%$ (the total score of respondents' answers score 3 and 4 divided by the total score or 1496/1600). The percentage of the level of service realization is high, meaning that the management has been able to meet student expectations.

The description of the service quality expected by the students against the service delivered by the Accounting Department categorized in a certain quadrant is shown in the Importance-Performance Analysis quadrant (figure 2). Figure 2 is used by the management of the Accounting Department to make policies and decisions by looking at the indicators on service dimensions that have become achievements to be maintained and indicators on dimensions that are priority for improvement. 


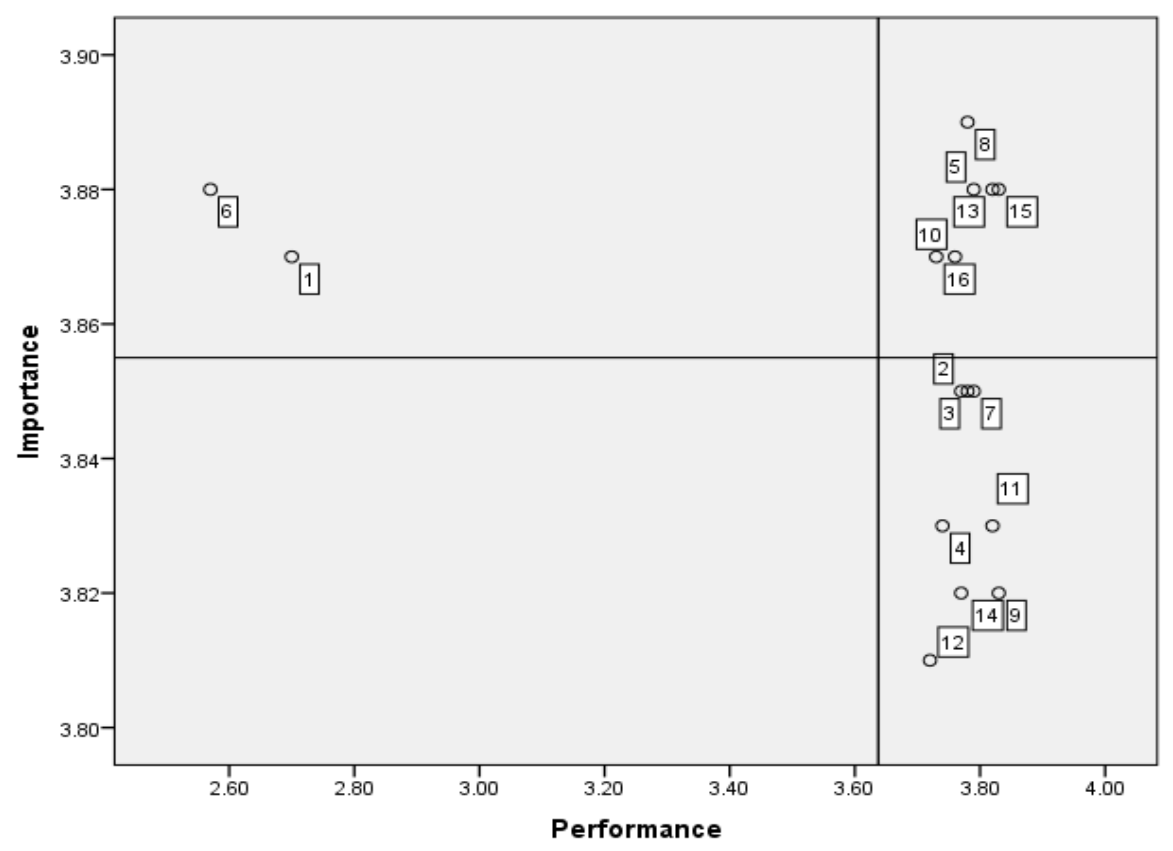

Figure 2. Importance Performance Analysis-Student Satisfaction

Based on Figure 2 can be analyzed the position of indicators and service dimensions as follows:

1. In quadrant A there are two indicators included in two dimensions, namely P1 indicator on tangible dimensions and P6 indicators on reliability dimension. In this quadrant it can be interpreted that the two indicators (P1 and P6) are service indicators that are very important as perceived by the students, but in reality the Polinema Accounting Department provides services of a quality that is not appropriate or below expectations. The service in this quadrant needs to be immediately improved by the Accounting Department.

2. In quadrant B there are six indicators, P5 on the reliability dimension, P8 on the responsiveness dimension, P10 and P13 indicators on the assurance dimension, and indicators P15 and P16 on the empathy dimension. These six indicators are the best form of service provided by the Accounting Department to students in accordance with high student service expectations. The quality of service in this quadrant needs to be maintained by the Accounting Department.

3. In quadrant D there are eight indicators namely P2 and P3 indicators on tangible dimensions, P4 indicators reliability dimensions, P7 and P9 indicators on responsiveness dimensions, P11 and P12 indicators on assurance dimensions, and P14 indicators on empathy dimensions. The eight indicators are the best form of Accounting Department services provided to students which is more than the students expectation The service quality of the indicators in quadrant D for the short term can be ignored.

4. There is no indicator entered in quadrant $\mathrm{C}$.

The high level of response (response rate) is supported by the ease of getting respondents. The high number of female respondents reflects their dominance in the the composition of students in the Accounting Department. The result of the calculation of student satisfaction index shows that in general students of the Accounting Department are very satisfied with the services received, approaching the maximum quality of service expected. It can be understood that Polinema is one of the best vocational higher education institutions in Indonesia, which is supported by human resources and very adequate infrastructure that is recognized by the public where the Accounting Department and the State Polytechnic of Malang has been accredited excelent. The Accounting Department is also one of the favorite institution in State Polytechnic of Malang.

There in only one indicator in the tangible dimension which fall to the catagory of "satisfying", namely the one related to the availability of classrooms and laboratory for the teaching learning process. This is possible because the Accounting Department has problems in the availability of classrooms and laboratory for the teaching learning process during the research period because in the even semester 2018/2019 there are preparations for reconstuction of 2 (two) buildings where teaching learning activities are conducted. This conditions might have cause the students to perceive that there expectations are less optimally met. The are the two quality services on tangible dimensions, namely the availability of equipment in classrooms and laboratory (Computers / LCD / AC) for the 
learning process and the sophistication of technology / equipment used in the learning process are considered "very satisfying" by students.

Regarding the reliability dimension there is also one indicator which fall to the catagory of only "satisfying", namely services related to the teaching skill for practical subjects. The possible reason for this unfavourable situation is the lack of appropriate practical material and the lack of practical knowledge of the lecturers. Students might perceive that the material given by the lecturer does not describe the real world of practice and / or the lecturer is not able to give examples of cases in the real world of practice. This might be do to the lack of lecturers training and experience in the field of the subject being taught, and this, in turns lead to the students to perceive that their expectations are less optimally fulfilled. The other hand, the two services quality on the reliability dimension, namely the ability of lecturers to deliver learning material and the timeliness of lecturers in carrying out learning activities, are considered "very satisfying" by students.

The service quality in the responsiveness dimension consists of the speed of the study program / department's response to events and feedback, the sincerity of the administrative staff in providing services and the willingness of lecturers to provide services outside of teaching hours are all rated "very satisfying" by students. Service quality in the assurance dimension consists of the expertise and skills possessed by administrative staff in providing services, the polite attitude of administrative staff in providing services, administrative staff responsibilities in providing services, and the ability to provide a sense of security and without hesitation (firmness) of administrative staff in providing services are all rated "very satisfying" by students. Service quality on the empathy dimension consists of the willingness of study programs / department to listen to student complaints, communication between study programs / department with students and the availability of administrative staff personnel, study programs / department during service hours are all also considered "very satisfying" by students

\section{Conclusion}

Based on the results and previous discussions, it was concluded that the response rate was very high because of the ease of getting respondents. Most of the respondents came from the DIV Managemet Accounting study program with a higher percentage of female respondents than male respondents. The frequency of answers to the quality of services received by students (performance) is mostly satisfying $23 \%$ and very satisfying $71 \%$. The quality of service received by students in general is very satisfying, whereas specifically there are two forms of service whose quality is judged to be only "satisfying" by students, namely related to the availability of classrooms and laboratory for the teaching learning process and the practical skill of lecturers in the subject.

The results of the IPA analysis show that there are two dimensions in quadrant A where the service quality in this quadrant is required to be immediately improved. The first issue is the availability of classrooms and laboratory for the teaching learning process because at the even semester 2018/2019 there are preparations for reconstuction of 2 (two) buildings where teaching learning activities are conducted. Second, the problem of practical skill of lecturers might be caused by the lack of practical content of the material and the lack of practical knowledge of lecturers. This might be caused by the lack of practical experience relevant to the field of the course being taught. There are four dimensions in quadrant B, namely the dimensions of reliability, responsiveness, assurance, and empathy which are indicated by six indicators of service forms that need to be maintained by the Accounting Department. In quadrant $\mathrm{D}$ there are all dimensions of service quality that are shown by eight indicators of services for the short term can be ignored.

To overcome the problem of limited classrooms and laboratory, management of the Accounting Department can choose internal or external solutions. Internal solution is done by rearranging and remanaging all academic rooms in the Accounting Department. An external solution is by coordinating with a central institution (Polinema) if alternative solutions for providing classrooms and laboratories are likely to use infrastructure beyond the control of the Accounting Department, for example using classrooms from other departments within the area of Polinema. To overcome the problem of practical skill of lecturers, the management of the Accounting Department can choose several alternative solutions, such as (a) establishing a teaching team consisting of senior-junior lecturers or those in charge of practical and theoritical lecturers, (b) holding training or the workshop presented by practitioner, (c) cooperating with industries for lecturer internships. 


\section{Reference}

Algifari. 2019. Mengukur Kualitas Layanan dengan Indeks Kepuasan, Metode Importance-Performance Analysis (IPA) dan Model Kano. Yogyakarta: BPFE.

Ambartiasari, G., Abdul R., L dan Syafruddin, C. 2017. Pengaruh Kualitas Pelayanan, Kepercayaan Dan Fasilitas Kampus Terhadap Kepuasan dan Dampaknya Kepada Loyalitas Mahasiswa Politeknik Indonesia Venezuela. Jurnal Manajemen dan Inovasi. Vol.8 No.3

Andreassen, W. \& Lindestad. 1997. The Impact of Corporate Image on Quality, Customer Satisfaction, and Loyalty for Customer with Varying Degrees of Service Expertise. The International Journal of Service Industry Management, 8(4),: 14-15.

Arambewela, R. dan Hall, J. 2009. An Empirical Model of International Student Satisfaction. Asia Pacific Journal of Marketing and Logistics, 21(4): p. 555-569.

Asih, Daru. 2011. Analisis Faktor Kualitas Layanan Administrasi Akademik Dalam Memberikan Kepuasan Kepada Mahasiswa Di Fakultas Ekonomi Dan Bisnis Universitas Mercu Buana Jakarta. Dari http://eprints.unisbank.ac.id/189/1/artikel-25.pdf. (Diakses tanggal 18 Maret 2019).

Bhakti, Y. B. dan Rahmawati, E. Y. 2017. Indeks Kepuasan Mahasiswa Terhadap Pelayanan Program Studi Pendidikan Matematika. Jurnal Formatif, 7(3). 272-285

Bindu, G. Mishra and Sita. 2009 Work Place Motivators and Employees' Satisfaction with Organization: A Study of Retail Sector in India. Indian Journal of Industrial Relations. Vol. 44, No. 3, 509-519.

Kardoyo dan Nurkhin, A. 2016. Analisis Kepuasan Pelayanan Perguruan Tinggi (Kasus Pada Prodi Magister Pendidikan Ekonomi Unnes). Cakrawala Pendidikan-Jurnal Ilmiah Pendidikan. XXXV, (2)

Kotler, Philip. 2002. Marketing Management. New Jersey: Printice Hall.

Kotler, P. dan Keller, K. 2006. Marketing Management: Customer Value, Customer Satisfaction And Customer Loyalty. 12th ed. Upper Saddle River: Prentice-Hall.

Lupiyoadi, R. dan Hamdani, A. 2008. Manajemen Kualitas Jasa. Jakarta: Salemba Empat.

Martilla, J.A dan James, J.C. 1977. Importance-Performance Analysis, Journal of Marketing. 41, 13-17.

Oldfield, B.M. and Baron, S. 2000. Student Perceptions of Service Quality in a UK University Business and Management Faculty. Quality Assurance in Education: An International Perspective. 8, 85-95.

Parasuraman, A. A. Zeithaml, V., and L. Berry, L. 1985. “A Conceptual Model of Service Quality and Its Implications for Future Research". Journal of Marketing. 49, 41-50

Sanusi, Anwar, 2014. Metodologi Penelitian Bisnis, Jakarta: Salemba Empat

Zeithaml, V. A., Berry, L. L. dan Parasuraman, A. 1996. The Behavioral Consequences of Service Quality. Journal of Marketing, 60(2) 31 